\title{
APPROACH OF SCALING THE LEVEL OF GOVERNMENT INTERVENTION IN THE FINANCIAL MARKET
}

\author{
Kristaps Freimanis ${ }^{1}$, Maija Šenfelde ${ }^{2}$ \\ Department of the Territorial Development Management and Urban Economics, Faculty of Engineering \\ Economics and Management, Riga Technical University, Kalnciema 6, LV-1048, Riga, Latvia \\ E-mails: ${ }^{1}$ kristaps.freimanis_5@rtu.lv(corresponding author); ${ }^{2}$ maija.senfelde@ 1 rtu.lv
}

Received 06 April 2020; accepted 05 May 2020

\begin{abstract}
In the field of the economics' regulation researchers so far have built the conceptual framework showing how the deadweight loss of market failures decrease and costs of the government intervention increase with the increased level of the government intervention. In order to quantify relationships between the level of intervention, intervention costs and the deadweight loss with econometric models it is important to understand how to apply coordinates for the data points to be included in the modelling. The main goal of the research presented in this paper is to find the unit measure for the asis of the independent variable, i.e. to shape the categorical scale corresponding to the level of intervention.
\end{abstract}

Keywords: categorical scale, deadweight loss, financial market regulation, market failure, government intervention.

JEL Classification: G18.

\section{Introduction}

Most of the authors of the textbooks in microeconomics describe market from the perfect competition perspective and then later introduce the concept of market failures showing why government intervention is needed to address inefficient resource allocation (e.g. Mankiw, 2009; Besanko \& Braeutigam, 2011; Rubinfeld \& Pindyck, 2013). Role of the government in this respect was emphasized already in Keynes' (1936) researches and later discussed in other researches (e.g. Arrow, 1970, 1985; Shubik, 1970; Bjornstad \& Brown, 2004; Hertog, 2010; Ajefu \& Barde, 2015; Rosengard \& Stiglitz, 2015; NSW, 2017). Scientists have built the conceptual framework showing how (a) the deadweight loss of market failures decrease and (b) costs of the government intervention increase with the increased level of the government intervention. In order to quantify relationships between the level of intervention, intervention costs and the deadweight loss with econometric models it is important to understand how to apply coordinates for the data points to be included in the modelling. On the asis of dependent variable (Y) as a unit measure is used the currency however on the asis of the independent variable (X) there is no clear unit measure. The aim of the research presented in this paper is to find the unit measure for the asis of the independent variable, i.e. to shape the categorical scale for the $\mathrm{X}$ asis corresponding to the level of intervention. To achieve this aim the following tasks have been set: (a) prepare the literature review, including current approaches in assessing the regulatory environment in the financial market, (b) find applicable approaches to be used for the scaling of the level of government intervention, (c) prepare the approach of scaling the level of government intervention based on the literature and identified gaps and (d) validate the approach to selected countries with different intervention policy approaches. On top of the literature review the following research method is used: statistical method of shaping the categorical scale.

\section{Market failures and regulation}

Bator (1958) structured the discussion regarding market failures introducing definitions and types of market failures. Previously it was more common to discuss each market failure separately, in particular incomplete competition expressed as the monopoly (e.g. Harberger, 1954). Currently there are various approaches how to classify market failures. Two types of market failures - externalities and public goods - are often viewed together (e.g. Mankiw, 2009; Besanko \& Braeutigam, 2011; Rubinfeld \& Pindyck, 2013; NSW, 2017) as they reflect nature of the good. As per Mankiw (2009) an externality arises when a person engages in an activity that influences the well-being of a bystander and yet neither pays nor receives any compensation for 
that effect. Public goods are characterized by excludability (whether people can be prevented from using the good) and rivalry in consumption (does one person's use of the good reduce another person's ability to use it). Separately under the topic of market structure another market failure - incomplete competition - is viewed (e.g. Mankiw, 2009; Besanko \& Braeutigam, 2011; Jehle \& Reny, 2011; Rubinfeld \& Pindyck, 2013; NSW, 2017). Information asymmetry, which gained its significance with Akerlof's "market for "lemons" (1970), Spence's “job market's signals" (1973) and Stiglitz's "theory of "screening"" (1975), in the textbooks of microeconomics has received less attention and often is reflected in terms of moral hazard and adverse selection (e.g. Besanko \& Braeutigam, 2011; Jehle \& Reny, 2011; Rubinfeld \& Pindyck, 2013), while policy makers even add to the information asymmetry additional dimension of the information failure (e.g. NSW, 2017). Rosengard and Stiglitz have named public goods as "incomplete markets" thereby more emphasizing the nature of market failure which has occurred there (Stiglitz, 2000; Rosengrad \& Stiglitz, 2015). And on top of that they introduced less common market failure "unemployment and other macroeconomic disturbances". Although economists often recognize unemployment as a problem in the economy it is not so common to classify it as a market failure. In authors' view it is related to the fact that market failures are often viewed under the framework of microeconomics however Rosengard and Stiglitz have taken additional macroeconomic perspective there (Stiglitz, 2000; Rosengrad \& Stiglitz, 2015).

When it comes to semantics there is no unified approach of how to name the loss which appears to the society when market failures occurs. Often it is called as "deadweight loss" emphasizing lost Gross Domestic Product as a "dead weight", however alternative name of "welfare loss" exists more emphasizing society's welfare loss due to not produced Gross Domestic Product. In the paper name of "deadweight loss" is preferred however when referring to the articles which use the name of "welfare loss" both names are presented. Authors note that other names are often used as well, e.g. "efficiency loss" referring to the Pareto efficiency, which can be observed in the Figure 1 as well.

In the financial market a great attention to the theory of market failures has been received after 2008's economic and financial crisis (e.g. Besley, 2010; Allen \& Carletti, 2013; Grochulski \& Morrison, 2014). Special attention received necessity for the macroprudential regulation as systemic risks were identified on top of financial risks faced by individual companies (Allen \& Carletti, 2013; Grochulski \& Morrison, 2014).

Starting from Keynes (1936) government's role in the regulation of economics has been discussed. In those discussions government's intervention in the economy is justified by market failures that have been occurred (Arrow, 1970, 1985; Shubik, 1970; Ajefu \& Barde, 2015). Often normative approach is followed (Rosengard \& Stiglitz, 2015), when market failures prescribe what government should do in order to achieve Pareto efficiency in the market. The practical guidance often is provided in various policy documents (e.g. Bjornstad \& Brown, 2004; NSW, 2017).

Initially no costs arising from the regulation were taken into account, however later this perspective appeared. Hertog (2010) in the analysis of previous research revealed three types of costs arising from the regulation (calling them as "intervention costs"): regulatory costs, compliance costs and indirect costs. These costs then were put into the context of welfare loss arising from market failures and the concept of the optimal level of welfare loss control were introduced (see Figure 1).

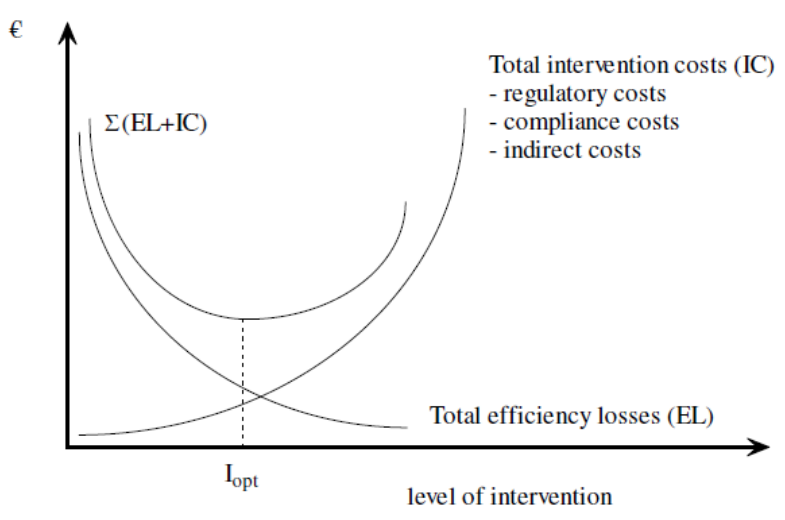

Figure 1. Optimal level of welfare loss control (source: Hertog, 2010)

This concept shows how (a) the deadweight (welfare) loss of market failures decrease and (b) costs of the government intervention in-crease with the increased level of the government intervention. And in this visualization it is clearly shown that it is efficient to mitigate market failure till the point were costs arising from regulations are lower than the deadweight (welfare) loss.

In order to quantify relationships between the level of intervention, intervention costs and the deadweight loss with econometric models it is important to understand how to apply coordinates for 
the data points to be included in the modelling. On the asis of dependent variable (Y) as a unit measure is used the currency however on the asis of the independent variable $(\mathrm{X})$ there is no clear unit measure.

\section{Existing approaches reused for the scaling}

In order to develop the categorical scale the current research was reviewed to seek for ideas how to assess different levels of government intervention. There (Agoraki et al., 2011; Anginer et al., 2014; Delis \& Kouretas, 2011) regulatory environment has been observed and evaluated by several indices which shows different angles of regulatory environment. Below are listed the indices and the main logic of questions from questionnaires or assessment logic relevant for the certain index regarding:

(a) Capital requirements - how conservative is the approach of calculating regulatory capital for the purpose of capital adequacy assessment, what is allowed as a capital injection.

(b) Supervisory power - what is the ability of supervisor to influence organizational structure, decisions related to capital and insolvency, rights to approach auditors.

(c) Activity restrictions - score is determined based on the evaluation of bank's restrictions to participate in securities, insurance activities, real estate activities and to own non-financial firms.

(d) Market discipline - what are requirements of banks in relation to public disclosures, what are liabilities for misleading the public etc.

(e) Diversification - are there in the certain jurisdiction available explicit, verifiable and quantifiable guidelines on the asset diversification; are banks permitted to issue loans abroad.

Authors reviewed all questions from the literature (Agoraki et al., 2011; Anginer et al., 2014; Delis \& Kouretas, 2011) and marked those, which in authors' view have impact on operation costs either to the bank or the supervisor/regulator (see Appendix 1).

Applicability in the Appendix 1 is marked as "Yes", non-applicability - "No". If costs arise to the bank, then it is marked as " $\mathrm{B}$ ". If costs arise to the supervisor, then - "S". Further in the section authors shortly describe the justification for applied marks, i.e. "Yes", "No", "B" and "S".

For the Capital requirements index all requirements, which are related to the proper calcula- tion of the regulatory capital, are marked as "Yes" as they could lead to the need to hold bigger amount of capital for the bank, which will impose additional costs for it. And some IT and human resource costs will appear as there is need to adjust IT systems and internal reporting procedures in order to report capital amounts properly. In other indices all items affecting reporting are treated as cost imposing as well due to the abovementioned effect on the IT systems and internal procedures.

Capital injections and structure (borrowed funds as initial disbursement) as well affect bank's costs from capital cost perspective taking into account that bank could be restricted to use more cheap resources.

For the Supervisory power index supervisor's rights to take legal action or measures against external auditors are treated as cost affecting right for the bank as auditors most probably will be more cautious in doubtful situations and will propose more conservative approaches which could be more expensive.

Supervisor's rights to order bank's management to constitute additional provisions will affect bank's costs directly and as well impose additional costs for supervisor himself as there will be need to use IT and human resources to check bank's financial accounts and find respective items.

Supervisor's rights to declare bank insolvent will impose additional costs for both - bank and supervisor - as there will be the need for supervisor to allocate resources for the information collection about the bank in order to prepare the resolution plan. And bank will face the need to allocate additional resources for the compliance with supervisor's requirements in this respect. Four questions which are mentioned next in the Table 1 to the abovementioned question are treated as nonapplicable as from the cost perspective they overlap.

Questions related to the Activity restrictions index are treated as non-applicable from the cost perspective as they limit bank's opportunities to maximize profit from asset allocation thereby here only opportunity cost occur (not gained income) however it is not observable from the financial statements of particular bank.

For the Market discipline index subordinated debt as a part of the capital is treated as cost affecting item as it is cheaper capital item compared to the ordinary shares or accrued profit.

Items that are related to public disclosure are treated as cost imposing for both - bank and supervisor - as there will be the need for supervisor 
to allocate resources for disclosed information verification.

Directors' legal liabilities for misleading or erroneous information are treated as cost imposing for the bank due to additional internal procedures which will be produced to minimize the risk of publishing misleading or erroneous information.

Mandatory credit ratings and certified auditor reports as well impose additional costs to the bank as services provided by credit rating agencies.

Deposit insurance protection system will impose additional costs to the bank in the form of regulatory requirements, while to the supervisor in the form of the system maintenance costs.

For the Diversification index guidelines are treated as supervisor's costs due to the need to allocate resources for the development of them.

Permission to make loans abroad is treated as an opportunity for the bank to seek better profits abroad thereby here is more income perspective reflected.

\section{Approach of scaling the level of government intervention}

Based on the review described in the previous section authors in the Appendix 2 have summarized the questions to be used for the scaling the level of government intervention from the cost perspective.

The logic of the score is following the suggestions of the literature (Agoraki et al., 2011; Anginer et al., 2014; Delis \& Kouretas, 2011), i.e. when certain requirement is treated as restrictive, however in this case logic is adjusted for the cost effect. Score is "1" when requirement is restrictive and imposing additional costs either for the bank or the supervisor, otherwise it is " 0 ". Total score is 0 , $1,2, \ldots$ or 21 . Those values shape the categorical scale for $\mathrm{X}$ asis in the Figure 1.

On top authors have identified few areas not covered by the questionnaires from the literature (Agoraki et al., 2011; Anginer et al., 2014; Delis \& Kouretas, 2011):

(a) Anti-Money Laundering/Combating the Financing of Terrorism (AML/CFT) - this area in recent years has got a lot of attention from the supervisor, significantly increasing operational costs for both: the supervisor and the bank. Non-compliance with those requirements have caused insolvency for the several banks in the Baltic region within few recent years.

(b) Fit and proper (suitability) requirements for the bank's management - in this area the Basel Committee on Banking Supervi- sion has issued guidelines (BCBS, 2015) and European Banking Authority has publicly disclosed the plans of introducing new requirements (EBA, 2019). This will impose additional costs for the banks as the scope of suitable candidates for highlevel vacancies will narrow.

Abovementioned gaps are added to the table in the Appendix 2 to the section of Supervisory power index.

\section{Validation of the methodology}

For the methodology's validation purpose the World Bank's database of the recently conducted survey on the bank regulation has been used (World Bank, 2019). This survey has defined questions in a different way compared to the literature on previously mentioned indices (Agoraki et al., 2011; Anginer et al., 2014; Delis \& Kouretas, 2011) thereby authors adjusted the scaling model (see Appendix 3) to be able to use results from abovementioned survey (all changes marked bold). On top of that for the idenfied gaps new questions have been selected from the World Bank's survey.

Additionally in the Appendix 3 questions have been numbered so later in the Table 1 it is more easy to follow-up on them.

Methodology's validation is performed for the selected countries: Germany, the United Kingdom (UK), the United States of America (USA) and the Russian Federation (Russia). Those countries have selected as they represent different approaches in the regulation of economy and subsequently financial market. It is expected that the most stringent regulatory requirements will be in Germany, followed by UK, USA and finally the less stringent requirements will be in Russia. Authors have set the hypothesis that the order of countries in their stringency of regulatory requirements will be as follows: Germany, UK, USA, Russia.

The rationale for such hypothesis is that Germany and USA are pretty different from the approach of how much government is allowed to regulate the economy. Germany has followed so called "social capitalism" approach where government is very actively regulating the economy. USA vice-versa has followed more liberal approach. UK has stayed somewhere in the middle between two abovementioned countries. Russia however has been less developed in the context of financial markets and their regulation and subsequently it is expected to have less regulatory requirements and associated costs imposed to the banks. 
Table 1. Scaling of intervention level for selected countries (source: authors' made based on World Bank, 2019)

\begin{tabular}{|c|c|c|c|c|}
\hline Question & Germany & UK & USA & Russia \\
\hline \multicolumn{5}{|c|}{ Capital requirements index } \\
\hline \multirow{2}{*}{1.} & Yes & Yes & Yes & Yes \\
\hline & 1 & 1 & 1 & 1 \\
\hline \multirow{2}{*}{2.} & Yes & No & No & No \\
\hline & 1 & 0 & 0 & 0 \\
\hline \multirow{2}{*}{3.} & Yes & Yes & Yes & Yes \\
\hline & 1 & 1 & 1 & 1 \\
\hline \multirow{2}{*}{4.} & Yes & Yes & Yes & Yes \\
\hline & 1 & 1 & 1 & 1 \\
\hline \multirow{2}{*}{5.} & Yes & Yes & Yes & No \\
\hline & 1 & 1 & 1 & 0 \\
\hline \multirow{2}{*}{6.} & No & No & No & No \\
\hline & 1 & 1 & 1 & 1 \\
\hline \multirow{2}{*}{7.} & Yes & Yes & Yes & No \\
\hline & 1 & 1 & 1 & 0 \\
\hline \multirow{2}{*}{8.} & Yes & Yes & Yes & Yes \\
\hline & 0 & 0 & 0 & 0 \\
\hline \multicolumn{5}{|c|}{ Supervisory power index } \\
\hline \multirow{2}{*}{9.} & Yes & No & Yes & Yes \\
\hline & 1 & 0 & 1 & 1 \\
\hline \multirow{2}{*}{10.} & Yes & Yes & Yes & Yes \\
\hline & 1 & 1 & 1 & 1 \\
\hline \multirow{2}{*}{11.} & Yes & Yes & Yes & Yes \\
\hline & 1 & 1 & 1 & 1 \\
\hline \multirow{2}{*}{12.} & No & No & No & No \\
\hline & 1 & 1 & 1 & 1 \\
\hline \multirow{2}{*}{13.} & Yes & No & Yes & Yes \\
\hline & 1 & 0 & 1 & 1 \\
\hline \multirow{2}{*}{14.} & Yes & Yes & Yes & Yes \\
\hline & 1 & 1 & 1 & 1 \\
\hline \multicolumn{5}{|c|}{ Market discipline index } \\
\hline \multirow{2}{*}{15.} & No & No & No & Yes \\
\hline & 1 & 1 & 1 & 0 \\
\hline \multirow{2}{*}{16.} & Yes & Yes & Yes & Yes \\
\hline & 1 & 1 & 1 & 1 \\
\hline \multirow{2}{*}{17.} & Yes & Yes & Yes & Yes \\
\hline & 1 & 1 & 1 & 1 \\
\hline \multirow{2}{*}{18.} & Yes & Yes & Yes & Yes \\
\hline & 1 & 1 & 1 & 1 \\
\hline & Yes & Yes & Yes & Yes \\
\hline 19. & 1 & 1 & 1 & 1 \\
\hline 20 & No & No & No & No \\
\hline & 0 & 0 & 0 & 0 \\
\hline 21 & Yes & Yes & No & Yes \\
\hline 21. & 1 & 1 & 0 & 1 \\
\hline ? & Yes & Yes & Yes & Yes \\
\hline 22. & 1 & 1 & 1 & 1 \\
\hline & Divers & ation $\mathrm{i}$ & & \\
\hline 23 & Yes & Yes & No & Yes \\
\hline 23. & 1 & 1 & 0 & 1 \\
\hline Total & 21 & 18 & 18 & 17 \\
\hline
\end{tabular}

Results show that abovementioned hypothesis is confirmed: the order of countries in their stringency of regulatory requirements is as follows: Germany, UK, USA, Russia.

\section{Conclusions}

In authors' view in general the approach works as expected from the viewpoint of regulatory requirements'stringency. The few notes here should be mentioned: (a) UK and USA are more close in their stringency of regulatory requirements than authors initially expected, (b) Russia has more stringent regulatory requirements than authors initially expected.

According to the approach stated in this paper the level of the government intervention in the financial market ( $\mathrm{X}$ asis in the diagram) can be scaled by the categorical scale with values $0,1,2$, ..., 23. Validation of this methodology showed that questions in the banking supervision surveys are changing reflecting changes in the regulatory frameworks thereby this methodology requires regular update and validation.

Authors recognize that it is very important to continue:

(a) the validation of this methodology with other countries as selected four countries give an initial understanding (snapshot) of whether there are no material deficiencies however further validation could shed light on new aspects which should be taken into account;

(b) the adjustment of the methodology with new realities our economies face, including climate change and epidemiological perspectives.

\section{Disclosure statement}

Authors declare that they do not have any competing financial, professional, or personal interests from other parties.

\section{References}

Agoraki, M.-E. K., Delis, M. D., \& Pasiouras, F. (2011). Regulations, competition and bank risk-taking in transition countries. Journal of Financial Stability, 7(1), 38-48.

https://doi.org/10.1016/j.jfs.2009.08.002

Ajefu, J. B., \& Barde, F. (2015). Market efficiency and government intervention revisited: What do recent evidence tell us? Journal of International Business and Economics, 3(1), 20-23. https://doi.org/10.15640/jibe.v3n1a3 
Akerlof, G. A. (1970). The market for "lemons": Quality uncertainty and the market mechanism. The Quarterly Journal of Economics, 84(3), 488-500. https://doi.org/10.2307/1879431

Allen, F., \& Carletti, E. (2013). Systemic risk from real estate and macro-prudential regulation. International Journal of Banking, Accounting and Finance, 5(1/2), 28-48. https://doi.org/10.1504/IJBAAF.2013.058091

Anginer, D., Demirguc-Kunt, A., \& Zhu, M. (2014). How does competition affect bank systemic risk? Journal of Financial Intermediation, 23(1), 1-26. https://doi.org/10.1016/j.jfi.2013.11.001

Arrow, K. J. (1970). The organization of economic activity: Issues pertinent to the choice of market versus nonmarket allocation. Public expenditure and policy analysis. Chicago: Rand MacNally College Publishing Company, 67-81.

Arrow, K. J. (1985). The potentials and limits of the market in resource allocation. In G. R. Feiwel (Ed.), Issues in contemporary microeconomics and welfare (pp. 107-124). Palgrave Macmillan. https://doi.org/10.1007/978-1-349-06876-0_2

Bator, F. M. (1958). The anatomy of market failure. The Quarterly Journal of Economics, 72(3), 351-379. https://doi.org/10.2307/1882231

BCBS. (2015). Corporate governance principles for banks. Basel Committee on Banking Supervision. https://www.bis.org/bcbs/publ/d328.pdf

Besanko, D., \& Braeutigam, R. (2011). Microeconomics ( $4^{\text {th }}$ ed., parts 1 , pp. 4-7). John Wiley \& Sons, Inc.

Besley, T. (2010). How do market failures justify interventions in rural credit markets? The World Bank Research Observer, 9(1), 27-47. https://doi.org/10.1093/wbro/9.1.27

Bjornstad, D. J., \& Brown, M. A. (2004). A market failures framework for defining the government's role in energy efficiency. Joint Institute for Energy and Environment, JIEE 2004-02.

Delis, D. M., \& Kouretas, G. P. (2011). Interest rates and bank risk-taking. Journal of Banking \& Finance, 35(4), 840-855. https://doi.org/10.1016/j.jbankfin.2010.09.032

EBA. (2019). Risk reduction package roadmaps. European Banking Authority. https://eba.europa.eu/sites/default/documents/files/ docu-

ment_library//EBA\%20Risk\%20Reduction\%20Pa ckage \%20Roadmaps.docx.pdf

Grochulski, B., \& Morrison, W. (2014). Understanding market failure in the 2007-08 Crisis. Economic Brief of Federal Reserve Bank of Richmond, EB14-12.

Harberger, A. C. (1954). Monopoly and resource allocation. The American Economic Review, 44(2), 7787.

Hertog, J. (2010). Review of economic theories of regulation (Discussion Paper Series 10-18). Tjalling C. Koopmans Research Institute.

Jehle, G. A., \& Reny, P. J. (2011). Advanced microeconomic theory $\left(3^{\text {rd }}\right.$ ed., chapters 4,8$)$. Pearson Education Limited.

Keynes, J. M. (1936). The general theory of employment, interest and money. Palgrave Macmillan.

Mankiw, N. G. (2009). Principles of microeconomics $\left(5^{\text {th }}\right.$ ed., parts $\left.2-5\right)$. South-Western Cengage Learning.

NSW. (2017). Market failure guide. A guide to categorising market failures for government policy development and evaluation. State of New South Wales through Department of Industry.

Rosengard, J. K., \& Stiglitz, J. E. (2015). Economics of the public sector $\left(4^{\text {th }}\right.$ ed., chapter 4$) . W . W$. Norton \& Company, Inc.

Rubinfeld, D. L., \& Pindyck, R. S. (2013). Microeconomics $\left(8^{\text {th }}\right.$ ed., parts 1,4$)$. Pearson Education, Inc.

Shubik, M. (1970). On different methods for allocating resources. KYKLOS, 23(2) 332-337. https://doi.org/10.1111/j.1467-6435.1970.tb02562.x

Spence, M. (1973). Job market signaling. The Quarterly Journal of Economics, 87(3), 355-374. https://doi.org/10.2307/1882010

Stiglitz, J. E. (1975). The theory of "screening", education, and the distribution of income. American Economic Review, 65(3), 283-300.

Stiglitz, J. E. (2000). Economics of the public sector ( $3^{\text {rd }}$ ed., chapter 4). W. W. Norton \& Company, Inc.

World Bank. (2019). Bank regulation and supervision survey.

https://www.worldbank.org/en/research/brief/BRSS 


\section{APPENDIX}

\section{Appendix 1}

Applicability of questions for the scaling of intervention level from the cost perspective (source: authors' made based on Agoraki et al., 2011; Anginer et al., 2014; Delis \& Kouretas, 2011)

\begin{tabular}{|c|c|}
\hline Question & Applicable \\
\hline \multicolumn{2}{|l|}{ Capital requirements index } \\
\hline Is the minimum required capital asset ratio risk-weighted in line with Basel guidelines? & Yes/ B/S \\
\hline Does the ratio vary with market risk? & Yes/B \\
\hline $\begin{array}{l}\text { Before minimum capital adequacy is determined, whether this item is deducted from the book val- } \\
\text { ue of capital: market value of loan losses not realized in accounting books? }\end{array}$ & Yes/ B \\
\hline $\begin{array}{l}\text { Before minimum capital adequacy is determined, whether this item is deducted from the book val- } \\
\text { ue of capital: unrealized losses in securities portfolios? }\end{array}$ & Yes/B \\
\hline $\begin{array}{l}\text { Before minimum capital adequacy is determined, whether this item is deducted from the book val- } \\
\text { ue of capital: Unrealized foreign exchange losses? }\end{array}$ & Yes/ B \\
\hline Are the sources of funds to be used as capital verified by the regulatory/ supervisory authorities? & Yes/S \\
\hline $\begin{array}{l}\text { Can the initial or subsequent injections of capital be done with assets other than cash or govern- } \\
\text { ment securities? }\end{array}$ & Yes/ B \\
\hline Can initial disbursement of capital be done with borrowed funds? & Yes/ B \\
\hline \multicolumn{2}{|l|}{ Supervisory power index } \\
\hline $\begin{array}{l}\text { Does the supervisory agency have the right to meet with external auditors to discuss their report } \\
\text { without the approval of the bank? }\end{array}$ & No \\
\hline $\begin{array}{l}\text { Are auditors required by law to communicate directly to the supervisory agency any presumed in- } \\
\text { volvement of bank directors or senior managers in illicit activities, fraud, or insider abuse? }\end{array}$ & No \\
\hline Can supervisors take legal action against external auditors for negligence? & Yes/B \\
\hline Can the supervisory authorities force a bank to change its internal organizational structure? & No \\
\hline Are off-balance sheet items disclosed to supervisors? & Yes/ B \\
\hline $\begin{array}{l}\text { Can the supervisory agency order the bank's directors or management to constitute provisions to } \\
\text { cover actual or potential losses? }\end{array}$ & Yes/ B/ S \\
\hline Can the supervisory agency suspend director's decision to distribute dividends? & No \\
\hline Can the supervisory agency suspend director's decision to distribute bonuses? & No \\
\hline Can the supervisory agency suspend director's decision to distribute management fees? & No \\
\hline Can the supervisory agency supersede bank shareholder rights and declare bank insolvent? & Yes/ B/S \\
\hline $\begin{array}{l}\text { Does banking law allow supervisory agency or any other government agency (other than court) to } \\
\text { suspend some or all ownership rights of a problem bank? }\end{array}$ & No \\
\hline $\begin{array}{l}\text { Regarding bank restructuring and reorganization, can the supervisory agency or any other govern- } \\
\text { ment agency (other than court) supersede shareholder rights? }\end{array}$ & No \\
\hline $\begin{array}{l}\text { Regarding bank restructuring \& reorganization, can supervisory agency or any other government } \\
\text { agency (other than court) remove and replace management? }\end{array}$ & No \\
\hline $\begin{array}{l}\text { Regarding bank restructuring \& reorganization, can supervisory agency or any other government } \\
\text { agency (other than court) remove and replace directors? }\end{array}$ & No \\
\hline \multicolumn{2}{|l|}{ Activity restrictions index } \\
\hline Restriction to participate in securities activities & No \\
\hline Restriction to participate in insurance activities & No \\
\hline Restriction to participate in real estate activities & No \\
\hline Restriction to own non-financial firms & No \\
\hline \multicolumn{2}{|l|}{ Market discipline index } \\
\hline Is subordinated debt allowable (or required) as part of capital? & Yes/B \\
\hline $\begin{array}{l}\text { Are financial institutions required to produce consolidated accounts covering all bank and } \\
\text { bank financial subsidiaries? }\end{array}$ & Yes/ B \\
\hline
\end{tabular}




\begin{tabular}{|l|c|}
\hline Question & Applicable \\
\hline Are off-balance sheet items disclosed to public? & Yes/ B/ S \\
\hline Must banks disclose their risk management procedures to public? & Yes/ B/ S \\
\hline Are directors legally liable for erroneous/ misleading information? & Yes/ B \\
\hline Do regulations require credit ratings for commercial banks? & Yes/ B \\
\hline Is an external audit by certified/licensed auditor a compulsory obligation for banks? & Yes/ B \\
\hline $\begin{array}{l}\text { Does accrued, though unpaid interest/ principal enter the income statement while loan is non- } \\
\text { performing? }\end{array}$ & No \\
\hline Is there an explicit deposit insurance protection system? & Yes/B/S \\
\hline Diversification index & Yes/S \\
\hline Are there explicit, verifiable, and quantifiable guidelines regarding asset diversification? & No \\
\hline Are banks permitted to make loans abroad? & \\
\hline
\end{tabular}

\section{Appendix 2}

Scaling the level of government intervention from the cost perspective (source: authors' made based on Agoraki et al., 2011; Anginer et al., 2014; Delis \& Kouretas, 2011)

\begin{tabular}{|c|c|}
\hline Question & Score \\
\hline \multicolumn{2}{|l|}{ Capital requirements index } \\
\hline Is the minimum required capital asset ratio risk-weighted in line with Basel guidelines? & $\begin{array}{l}\text { Yes }=1 \\
\text { No }=0\end{array}$ \\
\hline Does the ratio vary with market risk? & $\begin{array}{l}\text { Yes }=1 \\
\text { No }=0\end{array}$ \\
\hline $\begin{array}{l}\text { Before minimum capital adequacy is determined, whether this item is deducted from the book val- } \\
\text { ue of capital: market value of loan losses not realized in accounting books? }\end{array}$ & $\begin{array}{l}\text { Yes }=1 \\
\text { No }=0\end{array}$ \\
\hline $\begin{array}{l}\text { Before minimum capital adequacy is determined, whether this item is deducted from the book val- } \\
\text { ue of capital: unrealized losses in securities portfolios? }\end{array}$ & $\begin{array}{l}\text { Yes }=1 \\
\text { No }=0\end{array}$ \\
\hline $\begin{array}{l}\text { Before minimum capital adequacy is determined, whether this item is deducted from the book val- } \\
\text { ue of capital: Unrealized foreign exchange losses? }\end{array}$ & $\begin{array}{l}\text { Yes }=1 \\
\text { No }=0\end{array}$ \\
\hline Are the sources of funds to be used as capital verified by the regulatory/ supervisory authorities? & $\begin{array}{l}\text { Yes }=1 \\
\text { No }=0\end{array}$ \\
\hline $\begin{array}{l}\text { Can the initial or subsequent injections of capital be done with assets other than cash or govern- } \\
\text { ment securities? }\end{array}$ & $\begin{array}{l}\text { Yes }=0 \\
\text { No }=1\end{array}$ \\
\hline Can initial disbursement of capital be done with borrowed funds? & $\begin{array}{l}\text { Yes }=0 \\
\text { No }=1\end{array}$ \\
\hline \multicolumn{2}{|l|}{ Supervisory power index } \\
\hline Can supervisors take legal action against external auditors for negligence? & $\begin{array}{l}\text { Yes }=1 \\
\text { No }=0\end{array}$ \\
\hline Are off-balance sheet items disclosed to supervisors? & $\begin{array}{l}\text { Yes }=1 \\
\text { No }=0\end{array}$ \\
\hline $\begin{array}{l}\text { Can the supervisory agency order the bank's directors or management to constitute provisions to } \\
\text { cover actual or potential losses? }\end{array}$ & $\begin{array}{l}\text { Yes }=1 \\
\text { No }=0\end{array}$ \\
\hline Can the supervisory agency supersede bank shareholder rights and declare bank insolvent? & $\begin{array}{l}\text { Yes }=1 \\
\text { No }=0\end{array}$ \\
\hline $\begin{array}{l}\text { Identified gap: Are there requirements in the area of Anti-Money Laundering/ Combating the Fi- } \\
\text { nancing of Terrorism (AML/CFT) }\end{array}$ & $\begin{array}{l}\text { Yes }=1 \\
\text { No }=0\end{array}$ \\
\hline $\begin{array}{l}\text { Identified gap: Are there requirements regarding Fit and proper (suitability) requirements for the } \\
\text { bank's management }\end{array}$ & $\begin{array}{l}\text { Yes }=1 \\
\text { No }=0\end{array}$ \\
\hline \multicolumn{2}{|l|}{ Market discipline index } \\
\hline Is subordinated debt allowable (or required) as part of capital? & $\begin{array}{l}\text { Yes }=0 \\
\text { No }=1\end{array}$ \\
\hline
\end{tabular}




\begin{tabular}{|l|c|}
\hline Question & Score \\
\hline $\begin{array}{l}\text { Are financial institutions required to produce consolidated accounts covering all bank and any non- } \\
\text { bank financial subsidiaries? }\end{array}$ & Yes $=1$ \\
No $=0$ \\
\hline Are off-balance sheet items disclosed to public? & Yes $=1$ \\
& No $=0$ \\
\hline Must banks disclose their risk management procedures to public? & Yes $=1$ \\
& No $=0$ \\
\hline Are directors legally liable for erroneous/ misleading information? & Yes $=1$ \\
& No $=0$ \\
\hline Do regulations require credit ratings for commercial banks? & Yes $=1$ \\
& No $=0$ \\
\hline Is an external audit by certified/licensed auditor a compulsory obligation for banks? & Yes $=1$ \\
& No $=0$ \\
\hline Is there an explicit deposit insurance protection system? & Yes $=1$ \\
\hline Diversification index & No $=0$ \\
\hline Are there explicit, verifiable, and quantifiable guidelines regarding asset diversification? & Yes $=1$ \\
\end{tabular}

\section{Appendix 3}

Adjusted scaling of the level of government intervention from the cost perspective (source: authors' made based on Agoraki et al., 2011; Anginer et al., 2014; Delis \& Kouretas, 2011; Bank Regulation and Supervision Survey, 2019)

\begin{tabular}{|c|c|}
\hline Question & Score \\
\hline \multicolumn{2}{|l|}{ Capital requirements index } \\
\hline $\begin{array}{l}\text { 1. Is the minimum required capital asset ratio risk-weighted in line with Basel guidelines? } \\
\text { Is capital adequacy assessed based on Basel I, Basel II or Basel III? }\end{array}$ & $\begin{array}{l}\text { Yes }=1 \\
\text { No }=0\end{array}$ \\
\hline $\begin{array}{l}\text { 2. Does the ratio vary with market risk? } \\
\text { Whether regulatory minimum capital requirements cover credit, market, operational } \\
\text { and other risks? }\end{array}$ & $\begin{array}{l}\text { Yes }=1 \\
\text { No }=0\end{array}$ \\
\hline $\begin{array}{l}\text { 3. Before minimum capital adequacy is determined, whether this item is deducted from the book } \\
\text { value of capital: market value of loan losses not realized in accounting books? } \\
\text { Is the following item deducted from Tier } 1 \text { regulatory capital: unrealized losses in fair } \\
\text { valued exposures? }\end{array}$ & $\begin{array}{l}\text { Yes }=1 \\
\text { No }=0\end{array}$ \\
\hline $\begin{array}{l}\text { 4. Before minimum capital adequacy is determined, whether this item is deducted from the book } \\
\text { value of capital: unrealized losses in securities portfolios? } \\
\text { Is the following item deducted from Tier } 1 \text { regulatory capital: investment in the capital of } \\
\text { certain banking, financial and insurance entities which are outside the scope of consoli- } \\
\text { dation? }\end{array}$ & $\begin{array}{l}\text { Yes }=1 \\
\text { No }=0\end{array}$ \\
\hline $\begin{array}{l}\text { 5. Before minimum capital adequacy is determined, whether this item is deducted from the book } \\
\text { value of capital: Unrealized foreign exchange losses? } \\
\text { Is the following item deducted from Tier } 1 \text { regulatory capital: gain on sale related to se- } \\
\text { curitisation transactions? }\end{array}$ & $\begin{array}{l}\text { Yes }=1 \\
\text { No }=0\end{array}$ \\
\hline $\begin{array}{l}\text { 6. Are the sources of funds to be used as capital verified by the regulatory/ supervisory authori- } \\
\text { ties? } \\
\text { Is Tier } 3 \text { capital legally allowed in regulatory capital? }\end{array}$ & $\begin{array}{l}\text { Yes }=\mathbf{0} \\
\text { No }=1\end{array}$ \\
\hline $\begin{array}{l}\text { 7. Can the initial or subsequent injections of capital be done with assets other than cash or gov- } \\
\text { ernment securities? } \\
\text { Is leverage ratio applicable to the bank? }\end{array}$ & $\begin{array}{l}\text { Yes }=1 \\
\text { No }=0\end{array}$ \\
\hline $\begin{array}{l}\text { 8. Can initial disbursement of capital be done with borrowed funds? } \\
\text { Is Tier } 2 \text { capital legally allowed in regulatory capital? }\end{array}$ & $\begin{array}{l}\text { Yes }=0 \\
\text { No }=1\end{array}$ \\
\hline Super & \\
\hline
\end{tabular}




\begin{tabular}{|c|c|}
\hline Question & Score \\
\hline $\begin{array}{l}\text { 9. Can supervisors take legal action against external auditors for negligence? } \\
\text { In cases where the supervisor identifies that the bank has received an inadequate audit, } \\
\text { does the supervisor have the powers to take actions against bank or external auditor? }\end{array}$ & $\begin{array}{l}\text { Yes }=1 \\
\text { No }=0\end{array}$ \\
\hline 10. Are off-balance sheet items disclosed to supervisors? & $\begin{array}{l}\text { Yes }=1 \\
\text { No }=0\end{array}$ \\
\hline $\begin{array}{l}\text { 11. Can the supervisory agency order the bank's directors or management to constitute provisions } \\
\text { to cover actual or potential losses? }\end{array}$ & $\begin{array}{l}\text { Yes }=1 \\
\text { No }=0\end{array}$ \\
\hline $\begin{array}{l}\text { 12. Can the supervisory agency supersede bank shareholder rights and declare bank insolvent? } \\
\text { Is court approval required to supersede bank shareholder rights? }\end{array}$ & $\begin{array}{l}\text { Yes }=0 \\
\text { No }=1\end{array}$ \\
\hline $\begin{array}{l}\text { 13. Identified gap: Are there requirements in the area of Anti-Money Laundering/ Combating the } \\
\text { Financing of Terrorism (AML/CFT) } \\
\text { Does the banking supervisory agency have a specific mandate set out in written form for } \\
\text { the prevention of financial crime (anti-money laundering / combating financing of ter- } \\
\text { rorism)? }\end{array}$ & $\begin{array}{l}\text { Yes }=1 \\
\text { No }=0\end{array}$ \\
\hline $\begin{array}{l}\text { 14. Identified gap: Are there requirements regarding Fit and proper (suitability) requirements for } \\
\text { the bank's management } \\
\text { Are Fit and proper requirements for the Board and senior management mandatory? }\end{array}$ & $\begin{array}{l}\text { Yes }=1 \\
\text { No }=0\end{array}$ \\
\hline \multicolumn{2}{|l|}{ Market discipline index } \\
\hline $\begin{array}{l}\text { 15. Is subordinated debt allowable (or required) as part of capital? } \\
\text { Is subordinated debt allowed as part of Tier } 1 \text { capital? }\end{array}$ & $\begin{array}{l}\text { Yes }=0 \\
\text { No }=1\end{array}$ \\
\hline $\begin{array}{l}\text { 16. Are financial institutions required to produce consolidated accounts covering all bank and any } \\
\text { non-bank financial subsidiaries? } \\
\text { Are banks required to prepare consolidated accounts for accounting purposes? }\end{array}$ & $\begin{array}{l}\text { Yes }=1 \\
\text { No }=0\end{array}$ \\
\hline 17. Are off-balance sheet items disclosed to public? & $\begin{array}{l}\text { Yes }=1 \\
\text { No }=0\end{array}$ \\
\hline 18. Must banks disclose their risk management procedures to public? & $\begin{array}{l}\text { Yes }=1 \\
\text { No }=0\end{array}$ \\
\hline 19. Are directors legally liable for erroneous/misleading information? & $\begin{array}{l}\text { Yes }=1 \\
\text { No }=0\end{array}$ \\
\hline 20. Do regulations require credit ratings for commercial banks? & $\begin{array}{l}\text { Yes }=1 \\
\text { No }=0\end{array}$ \\
\hline $\begin{array}{l}\text { 21. Is an external audit by certified/licensed auditor a compulsory obligation for banks? } \\
\text { Is an audit by a professional external auditor required for all banks in your jurisdiction? }\end{array}$ & $\begin{array}{l}\text { Yes }=1 \\
\text { No }=0\end{array}$ \\
\hline 22. Is there an explicit deposit insurance protection system? & $\begin{array}{l}\text { Yes }=1 \\
\text { No }=0\end{array}$ \\
\hline \multicolumn{2}{|l|}{ Diversification index } \\
\hline $\begin{array}{l}\text { 23. Are there explicit, verifiable, and quantifiable guidelines regarding asset diversification? } \\
\text { Are there any regulatory rules or supervisory guidelines regarding asset diversification? }\end{array}$ & $\begin{array}{l}\text { Yes }=1 \\
\text { No }=0\end{array}$ \\
\hline
\end{tabular}

